\title{
Pulp tissue vacuolization and necrosis after direct pulp capping with calcium hydroxide and transforming growth factor- $\beta 1$
}

\author{
Sri Kunarti \\ Department of Conservative Dentistry \\ Faculty of Dentistry Airlangga University \\ Surabaya - Indonesia
}

\begin{abstract}
Mechanical pulp exposure by a rotary cutting instrument or a hand-cutting instrument often happens in deep caries. Application of protective dressing can protect the pulp from additional injury by facilitating healing and repair. Pulp capping has been suggested as one treatment of choice after pulp exposure to maintain pulp vitality. TGF- $\beta 1$ is growth factor that has important rule in wound healing. The application of $\mathrm{Ca}(\mathrm{OH})_{2}$ and exogenous TGF- $\beta 1$ as direct pulp capping tr4eatment must be experimented in-vivo to see the vacuolization and necrosis in 7, 14, and 21 days after application. This research was done in vivo experiment from orthodontic patients indicated for premolar extraction, between ages 10-15 years. A class V cavity preparation was created in the buccal aspect $1 \mathrm{~mm}$ above gingival margin until pulp exposure. Cavity was irrigated slowly with saline solution and dried with a sterile small cotton pellet. Group 1 calcium hydroxide was applied as manufacture procedure. Group 2, the sterile absorbable collagen membrane used, as inert carrier of TGF- $\beta 1$ was soaked with $5 \mu \mathrm{l}$. All groups were covered by a Teflon pledge to separate pulp capping agent from glass ionomer cement restoration. Teeth extracted in 7, 14 and 21 days after treatment. All samples were hystopathologically examined. There were significant difference of TGF- $\beta 1(p<0.05)$ in the vacuolization day $14^{\text {th }}$ and $21^{\text {th }}$ compared with $7^{\text {th }}$. there were not significant difference in necrosis for all variables. Vacuolization and necrosis decreased in the application of TGF- $\beta 1$.
\end{abstract}

Key words: direct pulp capping, $\mathrm{Ca}(\mathrm{OH})_{2}, \mathrm{TGF}-\beta 1$, vacuolization, necrosis

Correspondence: Sri Kunarti, c/o: Departemen Konservasi Gigi, Fakultas Kedokteran Gigi Universitas Airlangga. Jln. Mayjend. Prof. Dr. Moestopo no. 47 Surabaya 60132, Indonesia.

\section{INTRODUCTION}

The treatment maintaining pulp vitality could be done in pulp inflammation with diagnosis of reversible pulpitis. Pulp inflammation is caused by the opening of pulp space/perforation due to appliance wound or caries. Pulp protective dressing is needed to achieve speedy recovery and tissue repair.

Calcium hydroxide $\left[\mathrm{Ca}(\mathrm{OH})^{2}\right]$ has been used for more than seventy years and the main advantage is the capability to stimulate pulp tissue to form dentin bridge. However, calcium hydroxide also has some disadvantages such as: high $\mathrm{pH}(\mathrm{pH}=12,5)$ could cause liquivactive necrosis in most superficial pulp layer. ${ }^{1}$ Caustic effect is caused by high $\mathrm{pH}$, easily solved and triggering coagulation necrosis at the area between necrotic and vital pulp layer. ${ }^{2}$ Alkali $\mathrm{pH}$ of calcium hydroxide induces local necrosis in contact with pulp and neutralize acid produced during inflammation response. The alkali properties could increase the risk of pulp disorder and apical lesion. ${ }^{3}$ Multiple tunnel defect occurs during the formation of dentin bridge in which it would allow the entrance of bacteria and toxin into dentin resulting in treatment failure. ${ }^{4}$ Multiple tunnel defect is not only morphologic disorder in pulp permanent protection but also pulp biologic protective failure against bacteria. ${ }^{5}$ At the present the tendency of application development of dental material is tissue engineering and growth factor which is a new approach based on cellular and molecular mechanism on dentinogenesis regulation during dental tissue repair and the capability of clinical exploitation, ${ }^{6}$ especially, either in vivo or in vitro study using TGF- $\beta 1$. The study has been done on the application of TGF- $\beta 1$ in rat molar using direct pulp capping. ${ }^{3}$ This material is multipotent physiologic molecule, regulating growth and development, inducing trauma recovery as well as regenerating tissue. Through receptor binding mechanism, signal transduction and gene activation would cause cell proliferation and secretion of extra cellular matrix to be reparative dentin. ${ }^{6}$ Transforming growth factor- $\beta 1$ would increase the formation of reparative dentin compared with other growth factor such as: EGF, FGF, PDGF. ${ }^{3}$

Inflammation response is protective mechanism of pulp tissue which has injury such as trauma (mechanical, chemical) or due to bacterial invasion, then, followed by tissue repair or recovery. Inflammation response is an accumulative cellular and vascular incidence such as vacuolization and necrosis. Vacuolization is cell inflammation due to reversible hydropic change. If recovery process occurs, vacuolization will reduce, in contrast if inflammation increases so vacuolization will be higher, and 
also necrotic tissue will increase in severe inflammation. The purpose of this study is to know the effect of TGF- $\beta 1$ application against vacuolization and nicrotic pulp tissue.

\section{MATERIAL AND METHOD}

This study was done on orthodontic patient's premolar which required extraction. Anesthesia was done in buccal fold using $6 \mathrm{ml}$ Xylestesin F. Rubberdam and saliva ejector were used and $70 \%$ alcohol as disinfectant was applied in preparation on buccal side $1 \mathrm{~mm}$ above gingival

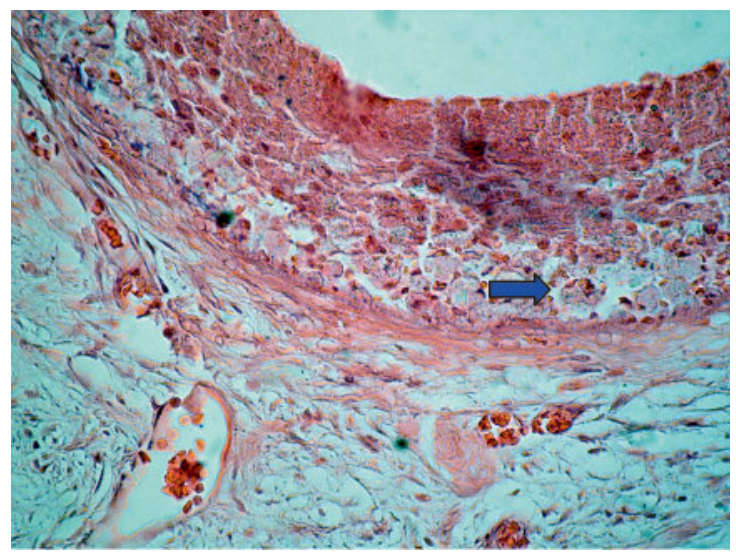

Figure 1. Vacuolization ( $\vec{a}$ ), the core directed to the edge pushed by intracellular liquid.

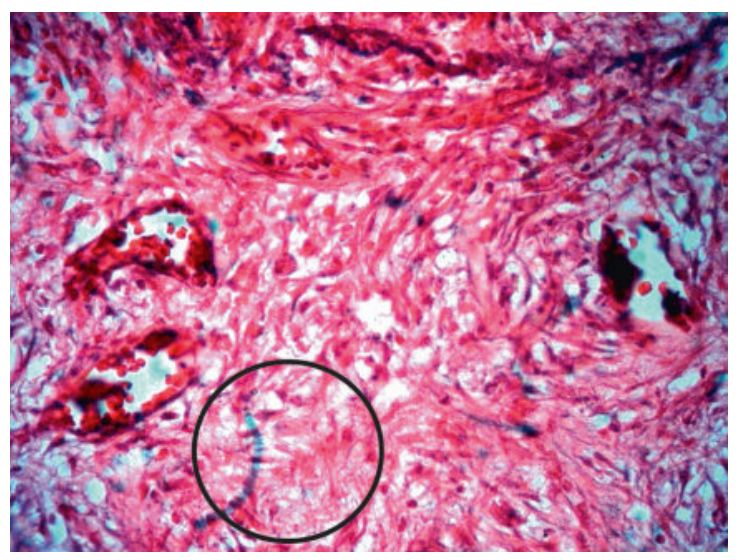

Figure 2. Necrotic area. margin. Light pressure intermittent drilling was also used. Preparation was done in a slanting direction toward the apical using no. 3 round drilling $1.5 \mathrm{~mm}$ in diameter approaching the pulp, then, using no. 1 round drilling with, $0.5 \mathrm{~mm}$ in diameter penetrating thin dentin layer perforating pulp space. Slowly cavity was irrigated using $0.5 \mathrm{ml}$ saline solution, then, it was dried cotton pellet sterile.

$\mathrm{Ca}(\mathrm{OH})_{2}$ visible light in $1 \mathrm{~mm}$ tube package (calcimol) applied on pulp and illuminated for 40 seconds. in another group, $20 \mathrm{ng} / \mathrm{ml}$ TGF- $\beta 1$ was used with by filling material of type II glass ionomer cement. Teflon pledged was applied to avoid the possibility of reaction between type II glass ionomer cement and pulp capping materials.

Hystophatologic preparation was made since tooth extraction was done. Fixation using $10 \%$ formaline buffer for 48 hours decalcification applying solution consist of $\mathrm{AlCl}$, formic acid, $37 \% \mathrm{HCl}$ and Aquadest. The next process would be dehydration with the purpose to extract water from tissue and replaced by medium which could be hardened (parafine), the next step clearing with xylene and infiltration hardening, tissue could be cut using microtom with $4 \mu \mathrm{m}$ thickness. The available preparation was stained using hemotocycline and eosin.

Evaluation of vacuolization was analyzed quantitatively (Figure 1). While necrosis evaluation was done based on criteria of score $1-4,{ }^{3,8,9}$ and it was read under microscope with graticule. Necrosis score $1=$ no necrotic tissue, $2=$ necrotic tissue is less or equal to $1 / 3$ of perforation width, $3=$ necrotic tissue is more than $1 / 3$ until $2 / 3$ of preparation width and $4=$ necrotic tissue more than $2 / 3$ of perforation width (Figure 2).

\section{RESULT}

Statistical parametric test was done to analyze rational scale of vacuolization number. The mean vacuolization of 7, 14, 12 day observation, after treatment TGF- $\beta 1$. The result of one way ANOVA test $\mathrm{Ca}(\mathrm{OH})_{2}$ group has shown insignificant difference $(\mathrm{p}>0.05)$ lower then control group TGF- $\beta 1$ group has shown significant difference $(p>0.05)$ between treatment variables.

Analysis result mean and standard deviation of vacuolization in $\mathrm{Ca}(\mathrm{OH})_{2}$ and TGF- $\beta 1$ group on 7,14 , and 21 day observation could be seen on the table 1.

Table 1. Mean and standard deviation of vacuolization in $\mathrm{Ca}(\mathrm{OH})_{2}$ group and TGF- $\beta 1$ in 7,14 , and 21 days after treatment

\begin{tabular}{cccccccc}
\hline \multirow{2}{*}{ Variable } & \multirow{2}{*}{ Material } & \multicolumn{2}{c}{7 days } & \multicolumn{2}{c}{14 days } & \multicolumn{2}{c}{21 days } \\
\cline { 3 - 8 } & & Mean & SD & Mean & SD & mMean & SD \\
\hline \multirow{2}{*}{ Vacuolization } & $\mathrm{Ca}(\mathrm{OH})_{2}$ & 13.1250 & 2.6424 & 9.8750 & 3.0909 & 12.2500 & 3.9551 \\
& $\mathrm{TGF}-\beta 1$ & 12.7500 & 2.1213 & 8.6250 & 2.9246 & 9.5000 & 2.4495 \\
\hline
\end{tabular}

SD: Standard deviation 
Through normality homogeneity test, unhomogenesis vacuolization data, Dunnet T3 test was done to analyze significant level. Kruskal Walis was done to analyze necrosis data, statistical analysis has shown significant decrease of TGF- $\beta 1$ comparison between $7-14$ days $(\mathrm{p}=0.004)$ and $7-21$ days $(\mathrm{p}=0.017)$. No significant difference on necrosis data analysis in both groups (Table 2).

Table 2. LSD test of vacuolization and necrosis comparison between $\mathrm{Ca}(\mathrm{OH})_{2}$ group and TGF- $\beta 1$ group in 7-14 days, 14-21 days and 7-21 days

\begin{tabular}{lccc}
\hline \multirow{2}{*}{ Variable } & \multirow{2}{*}{$\begin{array}{c}\text { Observation } \\
\text { time }\end{array}$} & \multicolumn{2}{c}{ P Value } \\
\cline { 3 - 4 } & & $\mathrm{Ca}(\mathrm{OH})_{2}$ & TGF- $\beta 1$ \\
\hline Vacuolization & $7-14$ days & 0.06 & 0.004 \\
& $7-14$ days & 0.599 & 0.017 \\
Necrosis & 14-21 days & 0.162 & 0.495 \\
& 7-14 days & 0.054 & 0.063 \\
& 7-14 days & 0.813 & 0.134 \\
& 14-21 days & 0.124 & 0.264 \\
\hline
\end{tabular}

Necrosis data taken from t-test comparison between TGF- $\beta 1$ and $\mathrm{Ca}(\mathrm{OH})_{2}$ in 21 days after treatment shows significant difference (Table 3 ).

Table 3. $\mathrm{t}$ test of vacuolization and necrosis comparison between $\mathrm{Ca}(\mathrm{OH})_{2}$ with TGF- $\beta 1$ in group 7,14 , and 12 day

\begin{tabular}{lccc}
\hline \multirow{2}{*}{ Variable } & \multicolumn{3}{c}{$\mathrm{P}$ Value $\mathrm{Ca}(\mathrm{OH})_{2}$ - TGF- $\beta 1$} \\
\cline { 2 - 4 } & 7 days & 14 days & 21 days \\
\hline Vacuolization & 0.759 & 0.420 & 0.117 \\
Necrosis & 0.143 & 0.143 & 0.038 \\
\hline
\end{tabular}

\section{DISCUSSION}

Significant difference and decreasing of mean value are found in comparison of vacuolization TGF- $\beta 1$ in 7,14 , and 21 days it shows that healing process due to the present of reversible degenerative vacuolar. Vacuole is inflammation cell which is also called hydropic change. Cytoplasm consists of cell containing fluid from invagination of cell membrane, endoplasmic dilatation of rough recticulum, and inflammation of mitochondria due to cell reaction on physical and pathological stimulation. Injury contributes loss of cell volume control. Usually, cell must secrete metabolic energy to pump out the secretion of natrium ion in order to maintain cell's internal environmental stability in which it occurs in cell membrane level. Anything disturbs cell metabolic energy or a little cell membrane injury could result cell disability to pump out adequate natrium, consequently, osmotic pressure change would occur in which natrium concentration in cell would increase or water would penetrate into cell resulting in morphologic change in the form of cell inflammation. ${ }^{10}$ This kind of change frequently happened in intra cell lipid accumulation. Microscopically, cytoplasm cell seemingly vacuolated in condition which is really similar to hydropic change. In this HE staining, lipid would dissolve during the process of preparation so it would appear as an empty space in which previously containing lipid ball. This degeneration process is reversible excepts the presence of continues possibly due to effect of $\mathrm{Ca}(\mathrm{OH})_{2}$ on day 7,14 , and 21 , the increase has been shown from day 14 until day 21 meaning that degenerative process still continues possibly due to the effect of $\mathrm{Ca}(\mathrm{OH})_{2}$ stimulation which contributes the imbalance of intercellular ion change caused by metabolic disturbance due to alkali $\mathrm{pH}$.

Significant difference $(\mathrm{p}=0.038)$ is found in necrosis comparison between TGF- $\beta 1$ and $\mathrm{Ca}(\mathrm{OH})_{2}$ on day 21 and lowering median value. Necrosis occurs because of disintegration of cell or autolysis and entrance of enzyme into tissue. Necrotic tissue would be cleaned by phagocytosis. Necrosis in $\mathrm{Ca}(\mathrm{OH})_{2}$ is possible due to alkali $\mathrm{pH}$ resulting in caustic effect on the underlying tissue. Morphologic appearance of necrotic tissue is different depends on the result of lytic activity on dead tissue. If the enzyme activity is inhibited by local condition, so necrotic cells would defend the form and tissue would defend the character for some time. This type of necrosis is called coagulation necrosis which is frequently found if necrosis is due to the loss of blood supply. ${ }^{10}$ In this study no significant difference in necrotic pulp tissue in 7, 14, 21 days, due to coagulated necrosis layer and it could happen for several days until several weeks. The region consists of debris, fragment of dentin, blood, material particle and inflammation cell and this region is also plasma protein which is denatured in obligation zone as caustic effect of pulp capping material. Demarcation line found between zone of coagulation necrosis and vital pulp tissue is resulting from material reaction with tissue protein forming globular protein layer for recovery purpose. ${ }^{11}$ Necrotic cell is shown by specific core change or the loss of the cell integrity resulting from damaging cell membrane. Necrosis median value in TGF- $\beta 1$ permanently in 7 days until 21 days after treatment, while median value in $\mathrm{Ca}(\mathrm{OH})_{2}$ is higher in 7 days until 14 days, then until 21 days.

The above description concludes that the use of TGF- $\beta 1$ would lower vacuolization and more necrotic tissue occurs in $\mathrm{Ca}(\mathrm{OH})_{2}$.

\section{REFERENCES}

1. Trope M, Chivian N, Sigurdsson A. Traumatic injuries. In: Cohen S, Burns RC, eds. Pathways of the pulp. $8^{\text {th }}$ ed. St Louis: Mosby Inc; 2002. p. 560-72.

2. Craig RG, Power JM, Wataha JC. Cement: Dental materials properties and manipulation. $7^{\text {th }}$ ed. St Louis: Mosby Inc; 2000. p. 129-31. 
3. Hu CC, Zhang C, Qian Q, Tatum NB. Reparative dentin formation in rat molars after direct pulp capping with growth factors. J Endod 1998; 24:744-51.

4. Gorecka V, Suliborski S, Biskupski T. Direct pulp capping with a dentin adhesive resin system in children's permanent teeth after traumatic injuries: case reports. Quintessence Int 2000; 31:241-48.

5. Cox CF, Subay RK, Ostro E, Suzuki S, Suzuki SH. Tunnel defects in dentin bridges: formation following direct pulp capping. Op Dent 1996; 21:4-11.

6. Goldberg M. Cell and extra cellular matrices of dentin and pulp: a biological basis for repair and tissue engineering. Crit Rev Oral Biol Med 2004; 15:13-27.

7. Holland R, De Souza V, De Mello W, Nery MJ, Bernabe PFE, Filho JAO. Permeability of the hard tissue bridge formed after pulpotomy with calcium hydroxide: a histologic study. J Am Dent Assoc 1979; 99:472-5
8. Tsuneda Y, Hayakawa T, Yamamoto H, Ikemi T, Nemoto K. A histopathological study of direct pulp capping with adhesive resins. Oper Dent 1995; 20:223-9.

9. Kitasako Y, Shibata S, Arakawa M, Cox CF, Tagami J. A light and transmission microscopic study of mechanically exposed monkey pulps. Oral Surg Oral Med Oral Pathol Oral Radiol Endod 2000; 89:224-30.

10. Abrams GD. Cedera dan kematian sel. In: Price SA, Wilson LM, eds. Patofisologi konsep klinik proses-proses penyakit. Cetakan ke-4. Indonesia. Jakarta: EGC; 1995. p. 22-33.

11. Stanley HR. Pulp capping: Conserving the dental pulp-Can it be done? Is it worth it? Oral Surg Oral Med Oral Pathol 1989; 68:628-39. 